\title{
Can a specialist parasite species of a widespread and common host species be rare? The case of Spinitectus inermis (Nematoda: Cystidicolidae) in eels Anguilla anguilla
}

\author{
Clive R. Kennedy
}

School of Biological Sciences, Hatherly Laboratories, University of Exeter, Exeter, UK

\begin{abstract}
The claim by many authors that Spinitectus inermis (Zeder, 1800), a narrowly specific parasite of European eels Anguilla anguilla (L.), is a rare species is considered at three levels: its geographical range, its frequency of occurrence compared to other eel parasites and its relative abundance in component communities. The parasite is widely distributed in freshwater throughout the European range of the eel but its occurrence is erratic and unpredictable, being known from only 8 countries. Surveys of eel parasites in the United Kingdom and in Continental Europe show that it is present in only 13\% of British and 29\% of continental localities. This satisfies one of the criteria for rarity. When present, its prevalence ranges from $1.8 \%$ to $43.3 \%$, so it can be considered rare in some localities but in a few it may be common and on occasion it may be the dominant species in the gastro-intestinal community. Populations of $S$. inermis are almost always characterised by high levels of overdispersion, even at low prevalence. The species also displays an ability to colonise a locality following introduction there. Overall it meets many of the criteria of a rare species including a restricted distribution and a low frequency of occurrence and so it can be considered to exhibit diffusive rarity.
\end{abstract}

Keywords: Spinitectus inermis, eel, geographical distribution, abundance, overdispersion, rarity

Rarity is an intuitive concept that is widely applicable and easy to recognise, but which is very difficult to define (Gaston 1994). In reality it is a relative term describing one end of a spectrum with common at the other end. When rarity is discussed in relation to biological communities it is almost invariably with reference to free-living species and in the context of biodiversity and conservation. Moreover, recognising that a species is rare frequently provokes measures for its protection. The question of whether a parasite species may be rare has seldom, if ever, been addressed. This may be due in part to feelings that issues of conservation and protection of parasites are not important and in part to a belief that only common and pathogenic parasite species have an important role in structuring communities of free-living organisms. Nevertheless, parasite rarity merits attention in its own right. It is becoming increasingly clear that parasites can impact on their hosts in very subtle ways; for example by manipulating intermediate host behaviour and so food webs (Poulin 1994, 2007, Moore 2002) and by facilitating the co-existence of competing host species thereby maintaining species diversity (Larsen et al. 2011) and so structuring host communities (Fenton and Brockhurst 2008).

In this context it is clearly important to determine not only whether a parasite species has an impact on its host but also whether a parasite species is rare. There is no a priori reason to assume that parasite species cannot also be aligned along the rare-common spectrum.

Recognition that a species is rare requires that its habitat be well known and studied across the geographical range of the species and preferably also that there be long-term studies on the species. When applying this concept to a parasite species, this means that the host(s), both definitive and intermediate, should have been identified and studied over their ranges; that the whole parasite community in each of its hosts has been fully censused and that the systematics of the species is not problematical. It is often tacitly assumed that a parasite species that is rare in one locality will be common in another, but this can only be confirmed or refuted if there are sufficient investigations throughout the range of the host(s) and parasite.

One of the few species of host and parasite to meet these stringent requirements are the European eel, $\mathrm{An}$ guilla anguilla (L.), and its parasite community. The eel is naturally widespread throughout Western Europe in rivers, lakes and coastal lagoons, and its range has been extended to landlocked inland waters by stocking and farming. Because of its commercial interest its parasite fauna is well known and has been studied throughout its range. This is particularly true of the gastro-intestinal 
helminth communities of eels, for which there are also some long-term investigations (Kennedy 1997, Kennedy and Moriarty 2002, Schabuss et al. 2005).

Whilst helminth infracommunities of eels may be relatively poor, component communities can be quite rich and comprise both specialist and generalist species (Kennedy and Guégan 1996, Norton et al. 2003, 2004). Some of these appear to be widespread and common throughout the host's range but others appear to have restricted geographical distributions and a few of these might be considered rare. Amongst them is the nematode Spinitectus inermis (Zeder, 1800) as it has only been recorded on relatively few occasions. Early workers (Dujardin 1845) described it as rare, a view that has been expressed by several more recent studies (Neveu-Lemaire 1927, Moravec 1977, 1979, 1985, 1994, Pilecka-Rapacz and Sobecka 2004). Because of this its life cycle has only fairly recently been elucidated (Saraiva and Eiras 1996, Saraiva and Moravec 1998, Saravia et al. 2002a,) and in experimental infections five species of ephemeropteran nymphs have been identified as intermediate hosts. However, it is still not known whether other species of aquatic insects can serve in this capacity. The species is easily recognisable and so is unlikely to be overlooked or misidentified in surveys. It is also very narrowly specific to A. anguilla, never having even been reported as an accidental species in another host (Moravec 1994). The aim of this study is therefore to determine whether $S$. inermis is truly a rare species with a restricted range and low abundance where it occurs or whether it is actually a species with peculiarities in its distribution and abundance that make it appear to be rare in parts of its range and/or in some localities.

\section{MATERIALS AND METHODS}

\section{Criteria of rarity}

Recognition of rarity depends upon the scale of the investigation over space and time (Gaston 1994, Kunin and Gaston 1997). Rare species are intuitively considered to have restricted geographical ranges and/or low abundances in localities in which they occur. Rarity can thus be measured as a proportion of censuses over a region in which a species occurs or as the relative abundance of a species in one or several communities. It is therefore necessary to examine the geographical range of a species and the frequency distribution of species abundance in a number of localities throughout its range.

\section{Data base}

The great majority of the data were obtained from published sources and these are identified as such in the text and tables. These were supplemented as necessary by further details of helminth dispersion patterns from my own raw data sets which have been summarised in the published literature. These are again identified as such. Only gastro-intestinal species are considered as these appear to represent a coherent and distinctive parasite community. Recognition of specialists and generalists follows normal practice and relies on knowledge of the eel as the preferred or only definitive host. Spinitectus inermis is unquestionably a specialist of eels, having never been recorded from any other fish species. Specialists and generalists are separated in the table because a generalist may be uncommon in eels but common in another species of fish: for a specialist the eel is the only definitive host and it does not have this alternative. Accidental species are excluded from some analyses. Surveys which did not provide full quantitative data on all gastro-intestinal species are excluded from consideration. In all cases the author's taxonomy has been accepted. Where there has been more than one study published on a particular locality only data sets that include $S$. inermis have been considered. All terminology follows that of Bush et al. (1997). Geographical distributional data are reported at river catchment level, to identify range, but component and infracommunity data are reported at tributary level for analysis of frequency distributions of species abundance by ranking and overdispersion of infrapopulations. Relative abundance is expressed at component community level as $p i$, the proportion of the total component community belonging to each species, in order to emphasise the relative differences between species. Simple mean abundance values are shown at infracommunity level.

\section{RESULTS}

\section{Geographical range}

All post-1900 records of the occurrence of Spinitectus inermis in eels in Europe are summarised in Table 1. Most records of the species in the 19th century have been excluded as they were either based on museum specimens and/or the place of eel capture was not recorded. It is probable that the record of Dujardin (1845) came from Germany. The parasite has been reported from localities right across Europe from the Baltic Sea and Poland in the north to the Mediterranean Sea and France in the south and from Portugal in the west to Yugoslavia in the east. It has also been found in central Europe, in the River Rhine in Germany and Switzerland. It has not been reported from a number of other countries in which eels are present and in which there have been detailed studies of eel parasites e.g., Denmark, Hungary, Ireland and Italy, and nor was it found in all surveys in countries in which it is known to be present, for example, Britain, Germany and Portugal. There is no pattern apparent in the presence or absence of $S$. inermis throughout the range of eels. The species is clearly widely distributed throughout the geographical range of eels but its occurrence appears to be erratic.

\section{Frequency of occurrence in component communities}

When the frequencies of occurrence of eel specialists and generalists are ranked across surveys (Table 2), it is clear that $S$. inermis is indeed a freshwater species and does not occur in coastal lagoons of enhanced salinity. This is in complete contrast to the trematode Deropristis inflata (Molin, 1859), which is the commonest species in lagoons and one of the rarest in freshwaters. S. inermis does not often occur in freshwaters but nor it is the least 
Table 1. The geographical distribution of Spinitectus inermis in eels in Europe.

\begin{tabular}{|c|c|c|}
\hline Location/catchment & Country & Authority \\
\hline $\begin{array}{l}\text { Mácha Lake, } \\
\text { River Elbe catchment }\end{array}$ & $\begin{array}{l}\text { Czech } \\
\text { Republic }\end{array}$ & Moravec $(1977,1979,1985)$ \\
\hline $\begin{array}{l}\text { Lake Bala, } \\
\text { River Dee catchment }\end{array}$ & England & Chubb (1963) \\
\hline River Exe catchment & England & Kennedy $(1997,2001)$ \\
\hline River Otter catchment & England & Kennedy (1997) \\
\hline River Thames catchment & England & Norton et al. (2003) \\
\hline $\begin{array}{l}\text { Etang, La Baillerie, } \\
\text { Banyuls-sur-Mer }\end{array}$ & France & Neveu-Lemaire (1927) \\
\hline River Elbe catchment & Germany & Schäperclaus (1954) \\
\hline River Rhine catchment & Germany & Thielen et al. (2007) \\
\hline Baltic Sea, off Chlapowo & Poland & Markowski (1933) \\
\hline Pomeranian rivers & Poland & $\begin{array}{l}\text { Pilecka-Rapacz and } \\
\text { Sobecka (2004) }\end{array}$ \\
\hline $\begin{array}{l}\text { River Sousa, } \\
\text { River Douro catchment }\end{array}$ & Portugal & $\begin{array}{l}\text { Saraiva and Eiras }(1996) \text {, } \\
\text { Saraiva et al. }(2002 a, b)\end{array}$ \\
\hline River Rhine, Laufenburg & Switzerland & Thielen et al. (2007) \\
\hline Lake Skadar and rivers & $\begin{array}{l}\text { former } \\
\text { Yugoslavia }\end{array}$ & $\begin{array}{l}\text { Ubelaker et al. (1981), } \\
\text { Kăzić et al. (1982) }\end{array}$ \\
\hline
\end{tabular}

frequent species. In England and Wales it was ranked fifth of the specialist species and was found in only $13.2 \%$ of the habitats studied, which included rivers, lakes and canals. When all species were considered, its ranking fell to tenth. On the continent, it was ranked third of the specialist species at $29.4 \%$ occurrence and seventh when all species were considered. The least common specialist species in all categories is clearly Goezia anguillae Lebre et Petter, 1983, which is ranked lowest in all categories and clearly meets the criteria of a rare species. However, $S$. inermis was reported from fewer than $25 \%$ of the localities in England and Wales and even on the continent its frequency is comparable at $29 \%$. It is less frequent than the majority of eel specialists and several species of generalists.

\section{Relative abundance in component communities}

The only consistent pattern in the frequency of occurrence and relative abundance of $S$. inermis in the seven localities for which the data are available (Table 3) is a significant positive correlation (Spearman's Rank Correlation, $\mathrm{r}=0.818, \mathrm{P}=0.0269$ ) between $p i$ and prevalence. In some localities, notably Lake Bala and the River Thames, it occurs at the lowest prevalence and relative abundance and so can clearly be categorised as rare. In others, the River Exe and the rivers Culm and Creedy, which are tributaries of the Exe, its prevalence levels are higher and it may even be the most prevalent species (River Exe). In terms of relative abundance as measured by the $p i$, it is the dominant species in the rivers Exe and Creedy. The low pi in the River Culm probably reflects the overwhelming numerical dominance of the acanthocephalan Pomphorhynchus laevis (Zoega in Müller, $1776)$ in the river. In the River Otter by contrast $S$. inermis is clearly the dominant species as reflected by both preva-
Table 2. The ranked relative frequency of occurrence of gastrointestinal helminth specialist species only in surveys of eels in Europe.

\begin{tabular}{|c|c|c|c|c|c|c|c|c|}
\hline & \multirow{2}{*}{\multicolumn{3}{|c|}{$\begin{array}{c}\text { British Isles } \\
\text { FW }\end{array}$}} & \multicolumn{5}{|c|}{ Continental Europe } \\
\hline & & & & & \multicolumn{2}{|l|}{ FW } & \multicolumn{2}{|c|}{ LAG } \\
\hline & \multirow[t]{2}{*}{$\%$} & \multicolumn{2}{|c|}{ Rank } & \multirow[t]{2}{*}{$\%$} & Rar & & $\%$ & Rank \\
\hline & & SPO & All & & SPO & All & & SPO \\
\hline \multicolumn{9}{|l|}{ Eel specialists } \\
\hline $\begin{array}{l}\text { Bothriocephalus } \\
\text { claviceps }\end{array}$ & 67.9 & 1 & 1 & 88.2 & 1 & 1 & 30.7 & 4 \\
\hline $\begin{array}{l}\text { Proteocephalus } \\
\text { macrocephalus }\end{array}$ & 35.8 & 3 & 5 & 76.4 & 2 & 2 & 53.8 & 2 \\
\hline $\begin{array}{l}\text { Acanthocephalus } \\
\text { clavula }\end{array}$ & 26.9 & 4 & 6 & 17.6 & $5=$ & $9=$ & 23.1 & 5 \\
\hline $\begin{array}{l}\text { Paraquimperia } \\
\text { tenerrima }\end{array}$ & 50.9 & 2 & 2 & 23.5 & 4 & 8 & 0 & - \\
\hline Spinitectus inermis & 13.2 & 5 & $10=$ & 29.4 & 3 & 7 & 0 & - \\
\hline Goezia anguillae & 1.9 & 7 & 14 & 11.7 & 7 & $12=$ & 7.6 & 6 \\
\hline Deropristis inflata & 5.7 & 6 & 13 & 17.6 & $5=$ & 11 & 92.3 & 1 \\
\hline $\begin{array}{l}\text { Lecithochirium } \\
\text { rudoviride }\end{array}$ & 0 & & - & 0 & - & - & 47.0 & 3 \\
\hline \multicolumn{9}{|l|}{ Generalists } \\
\hline Acanthocephalus lucii & 41.5 & & 4 & 52.9 & & $3=$ & & \\
\hline $\begin{array}{l}\text { Acanthocephalus } \\
\text { anguillae }\end{array}$ & 20.7 & & 7 & 47.5 & & 5 & & \\
\hline $\begin{array}{l}\text { Pomphorhynchus } \\
\text { laevis }\end{array}$ & 15.1 & & 8 & 35.2 & & 6 & & \\
\hline $\begin{array}{l}\text { Neoechinorhynchus } \\
\text { rutili }\end{array}$ & 13.2 & & $10=$ & 0 & & 0 & & \\
\hline $\begin{array}{l}\text { Echinorhynchus } \\
\text { truttae }\end{array}$ & 11.3 & & 12 & 17.6 & & $9=$ & & \\
\hline Raphidascaris acus & 43.3 & & 3 & 52.9 & & $3=$ & & \\
\hline Sphaerostoma bramae & 13.4 & & 9 & 11.7 & & $12=$ & & \\
\hline No. of localities sampled & 53 & & & 17 & & & 13 & \\
\hline
\end{tabular}

Key: FW = freshwater localities only; $\mathrm{LAG}=$ coastal lagoons with raised salinity, $\mathrm{SPO}=$ eel specialist species only, $\mathrm{All}=$ specialist and generalist species. The symbol $=$ denotes equal ranking. Accidental species are not included. All British localities are listed in Kennedy and Guégan (1996) with the addition of those listed in Kennedy et al. (1998), Kennedy (2001) and Norton et al. (2003, 2004). All marine lagoons are listed in Køie (1988a), Kennedy et al. (1997), Di Cave et al. (2001) and Outeiral et al. (2002). Continental localities are to be found in Seyda (1973), Kažić et al. (1982), Moravec (1985), Ubelaker et al. (1981), Muñoz (1994), Orecka-Grabda and Wierzbicka (1994), Saraiva and Eiras (1996), Schabuss et al. (1997, 2005), Borgsteede et al. (1999), Sures et al. (1999), Pilecka-Rapacz and Sobecka (2004) and Hermida et al. (2008).

lence and $p i$. The situation in the River Rhine is intermediate between the extremes, with a higher prevalence than Lake Bala and the River Thames but with a pi of a similar magnitude, perhaps again reflecting the numerical dominance by another species. Thus, in two localities $S$. inermis can be considered to be rare, in two others it is common and the dominant species, and in the remaining localities it is in intermediate positions along the rare to common continuum.

\section{Dispersion pattern in infrapopulations}

Infrapopulation data are seldom fully available in the published accounts of surveys, so the data presented in Table 4 may not be fully representative. Clearly the River 
Table 3. The occurrence and relative abundance of Spinitectus inermis in some gastro-intestinal helminth component communities in freshwater eels.

\begin{tabular}{|c|c|c|c|c|c|c|c|c|c|c|c|c|c|c|}
\hline \multirow[t]{2}{*}{ Species } & \multicolumn{2}{|c|}{ Lake Bala } & \multicolumn{2}{|c|}{ River Thames } & \multicolumn{2}{|c|}{ River Otter } & \multicolumn{2}{|c|}{ River Exe } & \multicolumn{2}{|c|}{ River Culm } & \multicolumn{2}{|c|}{ River Creedy } & \multicolumn{2}{|c|}{ River Rhine } \\
\hline & $\%$ & $p i$ & $\%$ & $p i$ & $\%$ & $p i$ & $\%$ & $p i$ & $\%$ & $p i$ & $\%$ & $p i$ & $\%$ & $p i$ \\
\hline Bothriocephalus claviceps & 18.0 & 0.04 & 41.0 & 0.10 & 16.6 & 0.03 & 20.7 & 0.2 & 10.1 & 0.02 & 20.7 & 0.12 & 0 & - \\
\hline Proteocephalus macrocephalus & 0 & - & 16.0 & 0.01 & 0 & - & 0 & - & 0 & - & 0 & - & 0 & - \\
\hline Sphaerostoma bramae & 0 & - & 0 & - & 0 & - & 0 & - & 5.4 & 0.02 & 0 & - & 0 & - \\
\hline Nicola gallica & 0 & - & 34.0 & 0.39 & 0 & - & 0 & - & 0 & - & 0 & - & 0 & - \\
\hline Acanthocephalus clavula & 27.7 & 0.59 & 0 & - & 0 & - & 0 & - & 16.2 & 0.02 & 0 & - & 0 & - \\
\hline Acanthocephalus anguillae & 0 & - & 44.0 & 0.34 & 0 & - & 0 & - & 0 & - & 0 & - & 0 & - \\
\hline Acanthocephalus lucii & 0 & - & 28.0 & 0.07 & 0 & - & 0 & - & 0 & - & 0 & - & 0 & - \\
\hline Pomphorhynchus laevis & 0 & - & 13.0 & 0.05 & 16.6 & 0.18 & 0 & - & 45.9 & 0.79 & 0 & - & 80.6 & 0.17 \\
\hline Echinorhynchus truttae & 0 & - & 0 & - & 0 & - & 0 & - & 5.4 & 0.01 & 0 & - & 41.7 & 0.02 \\
\hline Neoechinorhynchus rutili & 0 & - & 0 & - & 0 & - & 0 & - & 0 & - & 31.0 & 0.33 & 0 & - \\
\hline Paraquimperia tenerrima & 3.7 & $<0.01$ & 0 & - & 43.3 & 0.17 & 30.0 & 0.4 & 36.5 & 0.05 & 24.1 & 0.11 & 97.2 & 0.79 \\
\hline Spinitectus inermis & 1.8 & 0.01 & 6.0 & 0.01 & 43.3 & 0.57 & 40.0 & 0.4 & 18.9 & 0.06 & 20.7 & 0.44 & 23.1 & 0.02 \\
\hline Raphidascaris acus & 14.8 & 0.06 & 0 & - & 6.7 & 0.01 & 0 & - & 2.6 & 0.01 & 0 & - & 2.8 & 0.01 \\
\hline Cucullanus truttae & 11.1 & 0.29 & 0 & - & 0 & - & 0 & - & 1.3 & 0.01 & 0 & - & 0 & - \\
\hline Camallanus lacustris & 0 & - & 3.0 & $<0.01$ & 0 & - & 0 & - & 0 & - & 0 & - & 0 & - \\
\hline Pseudocapillaria tomentosa & 0 & - & 0 & - & 23.3 & 0.04 & 0 & - & 1.3 & 0.01 & 3.8 & 0.01 & 0 & - \\
\hline No. of eels & 54 & & 32 & & 30 & & 10 & & 74 & & 26 & & 61 & \\
\hline Source & Chut & 963 & $\begin{array}{l}\text { Nort } \\
\text { al. (2 }\end{array}$ & $\begin{array}{l}\text { on et } \\
003 \text { ) }\end{array}$ & $\begin{array}{r}\text { Ken } \\
\text { (unpul }\end{array}$ & $\begin{array}{l}\text { dy } \\
\text { shed) }\end{array}$ & & & & $\begin{array}{l}\text { edy } \\
1 \text { 1) }\end{array}$ & & $\begin{array}{l}\text { edy } \\
1 \text { 1) }\end{array}$ & & $\begin{array}{l}n \text { et } \\
07)\end{array}$ \\
\hline
\end{tabular}

Legend: $\%$ - prevalence, $p i$ - proportion of all gastro-intestinal helminth individuals. Accidental species included.

Exe catchment and the River Otter present particularly favourable conditions for $S$. inermis. Prevalence levels in both rivers are higher than those in all other British localities and in some continental localities and so are the majority of mean abundance values. The earlier low values in the River Otter reflect the fact that the parasite is a recent colonist of this river and its population was still increasing. In 7 out of the 15 Devon samples prevalence falls below $25 \%$, suggesting that the parasite may be uncommon in some samples, but in the remaining samples no clear pattern emerges. Abundance values tend to be higher where prevalence values are high.

The most striking feature of this data set lies in the intensity values and in the high degree of overdispersion revealed by the variance to mean ratios. In every sample the variance exceeds the mean, most notably in the River Otter in 1998. This appears to reflect the fact that some eels carry very heavy infections. Whilst some eels may harbour only one or two parasites, the majority harbour far more with maxima of 24 and 78. Even when prevalence and abundance values were low, as in the River Ribble, the single infected eel harboured 19 nematodes. The distributions of $S$. inermis are highly aggregated and if an eel is infected at all it is likely that it will harbour several parasites rather than a few and at least one eel in a sample can be expected to harbour heavy infections. The situation in the River Thames appears to be exceptional.

\section{DISCUSSION}

A species may be rare at one time in a locality but commoner at another time. It may have a wide spatial distribution but be common in some localities and rare in others.
It is also recognised that a species may have a restricted range but be common in the localities in which it occurs. It is particularly desirable (Schoener 1987) to determine whether a species is rare throughout its range and always occurs at low abundance (suffusive rarity) or whether it is common in some parts of its range and rare in others (diffusive rarity). For a species to be recognised as rare it is thus necessary to have an adequate knowledge of its range and abundance in the communities in which it occurs throughout that range. The problem is that rarity lies at one end of a continuum with common at the other and so is a relative concept. If defined in terms of abundance, Reveal (1981) considered rare species to be those "the abundances of which are restricted to a level less than the majority of other organisms of comparable taxonomic entities". In practice, it is necessary to decide at what point along this continuum a species is rare, and to consider it as a discontinuous variable, i.e. to define a cut-off point. This is the approach adopted and recommended by Gaston (1994) and Kunin and Gaston (1997). They suggested the cut-off point should be the first quartile, i.e. $25 \%$ of the distributions. They defined rarity in terms of occurrence throughout a range as species occurring in less than $25 \%$ of localities. Similarly species in the first quartile of the frequency distribution of abundance can be considered rare, whilst those occurring in over $75 \%$ are considered common. This is the approach that has been adopted in the present study.

A parasite species may also be rare if it is specific to a rare host species or to an endemic host species. A species may appear to be rare when it has only recently invaded a country or a habitat, as was initially the case with $S$. in- 
Table 4. Infrapopulation parameters of Spinitectus inermis in selected localities.

\begin{tabular}{|c|c|c|c|c|c|c|}
\hline River & Year & $\begin{array}{l}\text { No. of eels } \\
\text { examined }\end{array}$ & $\begin{array}{l}\text { Preva- } \\
\text { lence }\end{array}$ & $\begin{array}{c}\text { Mean } \\
\text { abundance }\end{array}$ & Intensity & $\begin{array}{l}\text { Variance/Mean } \\
\text { abundance }\end{array}$ \\
\hline \multicolumn{7}{|c|}{ (a) In Southwest England } \\
\hline \multicolumn{7}{|c|}{ Exe } \\
\hline Iron Bridge & 1999 & 7 & 28.6 & 1.86 & 6,7 & 10.8 \\
\hline Iron Bridge & 2000 & 6 & 50 & 2.16 & $1,4,8$ & 4.74 \\
\hline Stoodley & 2000 & 15 & 13.3 & 1 & 7,8 & 7.00 \\
\hline Bickleigh & 2000 & 15 & 13.3 & 1.93 & 6,23 & 18.8 \\
\hline \multicolumn{7}{|l|}{ Culm } \\
\hline Rewe & 1997 & 30 & 10.0 & 0.53 & $2,7,7$ & 6.2 \\
\hline Rewe & 1998 & 32 & 31.2 & 0.81 & $2,4,4,8$ & 3.6 \\
\hline Rewe & 1999 & 13 & 7.6 & 0.23 & 3 & 2.99 \\
\hline Rewe & 2000 & 25 & 8.0 & 0.62 & 3,10 & 6.97 \\
\hline \multicolumn{7}{|l|}{ Creedy } \\
\hline Cowley & 1999 & 26 & 23.0 & 1.26 & $1,1,2,3,6,20$ & 12.98 \\
\hline \multicolumn{7}{|l|}{ Otter } \\
\hline Bridge & 1991 & 16 & 12.5 & 0.2 & 1,2 & 1.6 \\
\hline Bridge & 1994 & 10 & 10 & 0.1 & 1 & - \\
\hline Bridge & 1995 & 98 & 26.5 & 1.5 & $18 \times 6,7,8,9,9,10,16,23,24$ & 11.1 \\
\hline Bridge & 1996 & 30 & 36.7 & 2.4 & $1,2,3,3,3,4,5,6,10,15,20$ & 9.5 \\
\hline Bridge & 1997 & 17 & 17.6 & 2.4 & $3,12,24$ & 18.9 \\
\hline Bridge & 1998 & 30 & 36.7 & 5.2 & $6 \times 4,8,10,24,29,78$ & 43.6 \\
\hline \multicolumn{7}{|c|}{ (b) In other British localities } \\
\hline Lake Bala & & 54 & 1.8 & 0.13 & 7 & 7.1 \\
\hline River Ribble & & 18 & 5.6 & 1.05 & 19 & 19.1 \\
\hline River Thames & & 32 & 6.2 & 0.12 & 2,2 & 1.1 \\
\hline \multicolumn{7}{|c|}{ (c) In some continental localities } \\
\hline River Sousa & & 326 & 57 max. & ND & $14 \max$ & \\
\hline Pomeranian rivers & & 272 & 6.6 & 0.19 & $10 \max$ & \\
\hline Lake Skadar & & 1033 & 0.98 & ND & 6 & \\
\hline Mácha Lake & & 32 & 9.3 & 0.47 & $1,1,12$ & \\
\hline River Rhine & & 36 & 23.2 & 1.3 & ND & \\
\hline
\end{tabular}

Sources: Rivers Exe, Culm and Creedy (Kennedy 2001), River Otter (Kennedy 1997 and unpublished), Lake Bala (Chubb, 1961), River Ribble (Kennedy unpublished), River Thames (Norton et al. 2003), River Sousa (Saraiva et al. 2002b), Pomeranian rivers (Pilecka-Rapacz and Sobecka 2004), Lake Skadar (Kăzić et al. 1982), Mácha Lake (Moravec 1985), River Rhine (Thielen et al. 2007).

ermis in eels in the River Otter in 1991 (Kennedy 1997, Table 4), or if one or more of its hosts approaches local extinction. It may become rare due to competition with an invasive species, as has been the case with the monogenean Gyrodactylus anguillae Ergens, 1960 on eels as a consequence of the spread of Pseudodactylogyrus species (Kennedy and Di Cave 1998) and Anguillicoloides novaezelandiae Moravec et Taraschewski, 1988 in Lake Bracciano in Italy following the arrival in the lake of A. crassus Kuwahara, Niini and Itagaki, 1974 (Moravec et al. 1994). It may also become rare if the definitive host remains common but the intermediate host(s) declines. This was exemplified in the case of Paratenuisentis ambiguus (Van Cleave, 1921) in the Rive Rhine: the species was common when its intermediate host Gammarus tigrinus Sexton was common (Sures et al. 1999), but later became rare and eventually disappeared when G. tigrinus disappeared (Sures and Streit 2001).

None of these circumstances however can explain the peculiar geographical distribution of $S$. inermis. The parasite is not present throughout the whole range of the European eel. Its absence from North Africa may simply reflect the paucity of studies on the helminth parasites of eels in that region, but that cannot be the explanation for its absence from Ireland (Holland and Kennedy 1997), Denmark (Køie 1988a,b), Spain (Muñoz 1994, Outeiral et al. 2002) or Belgium (Schabuss et al. 2005) as there have been several studies of eel parasites in these countries. There is no obvious pattern in its geographical distribution in contrast to the distribution, for example, of the nematode Rhabdochona anguillae Spaul, 1927, which appears to be restricted to southern Europe, in particular Spain, Portugal and Bulgaria, and for which eels may in fact only be an accidental host (Moravec 1994, Saraiva and Moravec 1998). This would seem to indicate that some other factor or factors may be affecting the distribution of a species that is able to increase in abundance very rapidly after its arrival in a new locality (Table 4).

One such factor may relate to the distribution of its intermediate hosts. Saraiva et al. (2002a) have determined experimentally that ephemeropteran (mayfly) nymphs can serve as the intermediate hosts of $S$. inermis. There may also be more suitable species as yet unidentified. The five species that they infected are restricted to freshwaters and prefer fast flowing stony waters such as occur in the upper reaches of rivers and shores of some lakes 
(Elliott and Humpesch 2010), although at least two of the species can also be found in the lower reaches of rivers. This explains the absence of the parasite from coastal lagoons of enhanced salinity in Italy (Kennedy et al. 1997, Di Cave et al. 2001) as the intermediate hosts cannot survive in these conditions. The presence of the parasite in eels in the Baltic (Markowski 1933) does not mean that the eel was infected there: more probably it was infected in freshwater and carried the parasite to sea with it. It would also explain why the parasite is generally absent from eels taken in the lower reaches of large rivers such as the Rhine (Thielen et al. 2007), the Thames (Norton et al. 2003, 2004) and the Tiber (Kennedy et al. 1998), and from slow flowing rivers in Belgium (Schabuss et al. 1997) and the Netherlands (Borgsteede et al. 1999). The absence of the parasite from some large lakes in central Europe, for example in Austria (Schabuss et al. 2005) and Hungary (Molnár and Székely 1995), may reflect the fact that the eels were not native to the lakes but were restocked into them as elvers which did not harbour the parasite: additionally many of these lakes are shallow and productive and would not provide the right habitat for the intermediate hosts.

At present, however, it is not easy to explain the absence of the parasite from Ireland, for example, where eels are common, there are many suitable habitats for mayflies and all the species that serve as intermediate hosts are present (Elliott and Humpesch 2010). Misidentification of the species would appear to be unlikely, as $S$. inermis has very obvious and characteristic features. The parasite does appear to show some seasonality in occurrence and maturation (Saraiva et al. 2002b) in eels, but it is present all through the year. It may simply be that $S$. inermis was never able to cross the Irish Sea and so colonise this island. Whatever the explanation for the patchy geographical distribution, the fact remains that it has only been recorded from eight European countries, on relatively few occasions and in only four catchments in England and Wales out of 43 surveyed. It is not surprising therefore that many workers including Moravec (1994) and Saraiva et al. (2002b) have referred to it as a rare parasite.

The ranked relative frequency of occurrence of the helminth parasites in eels in Britain (Table 2) would suggest that $S$. inermis is a rare species on a local scale. It occurred in fewer than $25 \%$ of the localities sampled, which is one of the criteria of rarity suggested by Gaston (1994). Its frequency on the continent exceeded the $25 \%$ quartile, but only by $4 \%$. It was never the rarest parasite of eels, as Goezia anguillae exhibited the lowest frequency of occurrence in both the British Isles and the Continental Europe. Both of these species also met the criteria of rarity suggested by Reveal (1981), since their frequencies of occurrence were restricted to a level less than the majority of other organisms of comparable taxonomic entities. On a local level (Table 3) there was no consistent pattern in the abundance of $S$. inermis in the localities for which appropriate data are available. The relationship between prevalence and $p i$ was predictable and is irrelevant in the context of rarity. The parasite could clearly be described as being rare in the River Thames and Lake Bala, but it was common and abundant in the helminth communities of the River Otter and also in the River Sousa in Portugal (Saraiva et al. 2002b). In the River Otter it became the dominant species in only 7 years after its first appearance there. The time series in this river (Table 4) showed that the parasite could increase in population size very rapidly following its introduction into a new locality but why it should be so abundant in only Portugal and southwest England is not at all clear.

An unexpected feature of the infrapopulations is the high degree of overdispersion of the parasite in most localities (Table 4) even when prevalence is very low, for example in the River Ribble. The values for the variance to mean ratio of abundances are very high and it is clear that in most samples there is at least one eel that is heavily infected. This might indicate that some individual eels feed selectively on the intermediate hosts whereas others just ingest them as a normal part of their diet. An unexpected consequence of this overdispersion is that estimates of the abundance of $S$. inermis have to be treated with caution as the chance presence or absence of one such heavily infected eel in a sample could have a significant effect on the estimation of the parasite's abundance.

The stated aim of the investigation was to determine whether $S$. inermis, a very specific parasite of the widespread and common eel, could be regarded as a rare species. Phrased like this, it implies that rarity may be a species-specific characteristic but this is not necessarily the case. The results do not provide an unequivocal answer. It meets several of the criteria of rarity in respect of geographical range and frequency of occurrence, but at the population level its abundance, both absolute and relative, is very variable and examples ranged right along the continuum from common to rare, with the River Otter at one extreme and Lake Bala at the other. What is clear is that if it is considered to be a rare species then it does not exhibit suffusive rarity, which is characterised by rarity in range and low abundance in all localities (Schoener 1987). As it can be common in some parts of its range, it must perforce exhibit diffusive rarity. The reality is that its distribution does not actually fit any consistent pattern, but it does suggest that a specific parasite of a common definitive host species can indeed be rare even if intermediate hosts are also common. This then leaves open the questions of why the species is not more widely distributed throughout its range and why it is not more abundant in those localities in which it occurs, given its proven ability to increase its population size so rapidly under suitable conditions.

Acknowledgements. I am very grateful to Phil and Jan Shears for all their technical assistance in the field and laboratory, and to Dr Frank Moravec for assistance with some obscure literature and for his helpful comments. 
Borgsteede F.H.M., Haenen O.L.M., De Bree J., Lisitsina O.L. 1999: Parasitic infections of European eel (Anguilla anguilla L.) in the Netherlands. Helminthologia 36: 251-260.

Bush A.O., Lafferty K.D., Lotz J.M., Shostack A.W. 1997: Parasitology meets ecology on its own terms: Margolis et al. revisited. J. Parasitol. 83: 575-583.

Снuвв J.C. 1963: On the characterisation of the parasite fauna of the fish of Llyn Tegid. Proc. Zool. Soc. Lond. 141: 609-621.

Di Cave D., Berrilli F., De Liberato C., Orecchia P., Kennedy C.R. 2001: Helminth communities in eels Anguilla anguilla from Adriatic coastal lagoons in Italy. J. Helminthol. 75: 7-13.

Dujardin M.F. 1845: Histoire Naturelle des Helminthes ou Vers Intestinaux. Paris, XVI, 669 pp.

Elliott J.M., Humpesch E.H. 2010: Mayfly larvae (Ephemeroptera) of Britain and Ireland: keys and a review of their ecology. Freshwater Biological Association Scientific Publication No. 66: $1-152$.

Fenton A., Brockhurst M.A. 2008: The role of specialist parasites in structuring host communities. Ecol. Res. 23: 795-804.

Gaston K.J. 1994: Rarity. Chapman \& Hall, London, 205 pp.

Hermida M., Saraiva A., Cruz C. 2008: Metazoan parasite community of a European eel (Anguilla anguilla) population from an estuary in Portugal. Bull. Eur. Ass. Fish Pathol. 28: 35-40.

Holland C.V., Kennedy C.R. 1997: A checklist of parasitic helminth and crustacean species recorded in freshwater fish from Ireland. Proc. Roy. Irish Acad. 97B: 225-243.

KažIĆ D., Ubelaker J.F., ĆAnkoviĆ M. 1982: [Endohelminths of eels (Anguilla anguilla Linne, 1758) of Skadar Lake and its tributaries.] Ichthyologia 14: 41-53.

KenNedy C.R. 1997: Long-term and seasonal changes in composition and richness of intestinal helminth communities in eels Anguilla anguilla of an isolated English river. Folia Parasitol. 44: $267-273$.

KenNeDY C.R. 2001: Metapopulation and community dynamics of helminth parasites of eels Anguilla anguillla in the River Exe system. Parasitology 122: 689-698.

Kennedy C.R., Berrilli F., Di Cave D., De Liberato C., OrecCHIA P. 1998: Composition and diversity of helminth communities in eels Anguilla anguilla in the River Tiber: long-term changes and comparison with insular Europe. J. Helminthol. 72: 301-306.

Kennedy C.R., Di CAVE D. 1998: Gyrodactylus anguillae (Monogenea): the story of an appearance and a disappearance. Folia Parasitol. 45: 77-78.

Kennedy C.R., Di Cave D., Berrilli F., Orecchia P. 1997: Composition and structure of helminth communities in eels Anguilla anguilla from Italian coastal lagoons. J. Helminthol. 71: 35-40.

Kennedy C.R., GuÉgan J.-F. 1996: The number of niches in intestinal helminth communities of Anguilla anguilla: are there enough spaces for parasites? Parasitology 113: 293-302.

Kennedy C.R., Moriarty C. 2002: Long term stability in the richness and structure of helminth communities in eels, $A n$ guilla anguilla, in Lough Derg, River Shannon, Ireland. J. Helminthol. 76: 315-322.

KøıE M. 1988a: Parasites in European eel Anguilla anguilla (L.) from Danish freshwater, brackish and marine localities. Ophelia 29: 93-118.

KøIE M. 1988b: Parasites in eels, Anguilla anguilla (L.), from eutrophic lake Esrom. Acta Parasitol. Pol. 33: 89-100.
Kunin W.E., Gaston K.J. 1997: The Biology of Rarity. Chapman \& Hall, London, $280 \mathrm{pp}$.

Larsen L.H., Jensen J.T., Mouritsen K.N. 2011: Climate influences parasite-mediated competitive release. Parasitology 138: 1436-1441.

Markowski S. 1933: Die Eingeweidewürmer der Fische de Polnischen Balticum (Trematoda, Cestoda, Nematoda, Acanthocephala). Arch. Hydrobiol. I Rybactwa, Suwalki. 7: 1-58.

Molnár K., Székely C. 1995: Parasitological survey of some important fish species of Lake Balaton. Parasit. Hung. 28: 63-82.

Moore J. 2002: Parasites and the Behaviour of Animals. Oxford University Press, Oxford, $338 \mathrm{pp}$.

MoRAVEC F. 1977: First record of the nematode Spinitectis inermis (Zeder, 1800) from eels of Czechoslovakia. Folia Parasitol. 24: 85.

Moravec F. 1979: Redescription of the nematode Spinitectus inermis parasitic in eels, Anguilla anguilla, of Europe. Věst Čs. Společ. Zool. 43: 35-42.

MoRAVEC F. 1985: Occurrence of endoparasitic helminths in eels (Anguilla anguilla (L.)) from the Mácha lake fishpond system, Czechoslovakia. Folia Parasitol. 32: 113-125.

Moravec F. 1994 Parasitic Nematodes of Freshwater Fishes of Europe. Kluwer, Dordrecht and Academia, Praha, 473 pp.

Moravec F., Di Cave D., Orrechia P., Paggi L. 1994: Present occurrence of Anguillicola novaezelandiae (Nematoda: Dracunculoidea) in Europe and its development in the intermediate host. Folia Parasitol. 41: 203-208.

Muñoz E.O. 1994: Parasitos y parasitismo de la anguila Anguilla anguilla $\mathrm{L}$. $\mathrm{PhD}$ thesis, Universitat de Valencia, $270 \mathrm{pp}$.

Neveu-Lemaire M. 1927: Un nematode parasite rare de l' anguille Spinitectus inermis (Zeder, 1800). Bull. Soc. Zool. France 52: 87-92.

Norton J., Lewis J.W., Rollinson D. 2003: Parasite infracommunity diversity in eels: a reflection of local component community diversity. Parasitology 127: 475-482.

Norton J., Lewis J.W., Rollinson D. 2004: Temporal and spatial patterns of nestedness in eel macroparasite communities. Parasitology 129: 203-211.

Orecka-Grabda T., Wierzbicka J. 1994: Metazoan parasites of the eel Anguilla anguilla (L.) in the Szczecin Lagoon and River Odra mouth area. Acta Ichthyol. Piscat. 14: 13-19.

Outeiral S., Alvarez M., Iglesias R., Paniagua E., Sanmartin M.L. 2002: Non-digenean parasites of eels from estuaries in Northwest Spain. Helminthologia 39: 91-97.

Pilecka-Rapacz M., Sobecka E. 2004: Nematodes of the intestine and swim bladder of the European eel Anguilla anguilla (L.) ascending Pomeranian rivers. Wiad. Parazytol. 50: 19-28.

Poulin R. 1994: The evolution of parasite manipulation of host behaviour: a theoretical analysis. Parasitology 109: 109-118.

Poulin R. 2007: Evolutionary Ecology of Parasites. Princeton University Press, Princeton, New Jersey, 332 pp.

Reveal J.L. 1981: The concepts of rarity and population threats in plant communities. In: L.E. Morse and M.S. Henefin (Eds.), Rare Plant Conservation. The New York Botanic Garden, Bronx, pp. 41-46.

Saraiva A., Eiras J.C. 1996: Parasite community of European eel, Anguilla anguilla (L.) in the River Este, Northern Portugal. Res. Rev. Parasitol. 56: 179-183. 
Saraiva A., Moravec F. 1998: Redescription of Rhabdochona anguillae (Nematode: Rhabdochonidae), a parasite of eel, Anguilla anguilla, in Europe. Folia Parasitol. 45: 233-238.

Saraiva A., Moravec F., Pereira A., Cruz C. 2002a: Development of Spinitectus inermis (Nematoda: Cystidicolidae), a parasite of eel, Anguilla anguilla, in Europe. Folia Parasitol. 49: 118-126.

Saraiva A., Pereira A., Cruz C. 2002b: Observations of the occurrence and maturation of Spinitectis inermis (Nematoda: Cystidicolidae) in the Sousa River, Portugal. Folia Parasitol. 49: 167-168.

Schabuss M., Kennedy C.R., Konecny R., Grillitsch B., Schiemer F., Herzig A. 2005: Long-term investigation of the composition and richness of intestinal helminth communities in the stocked population of eel, Anguilla anguilla, in Neusiedler See, Austria. Parasitology 130: 185-194.

Schabuss M., Konecny R., Belpaire C., Schiemer F. 1997: Endoparasitic helminths of the European eel, Anguilla anguilla, from four disconnected meanders from the rivers Leie and Scheldt in western Flanders, Belgium. Folia Parasitol 44: 12-18.
SCHÄPERClauS W. 1954: Fischkrankheite. Akademie-Verlag, Berlin, $708 \mathrm{pp}$.

SCHOENER T.W. 1987: The geographical distribution of rarity. Oecologia 74: 161-173.

Seyda M. 1973: Parasites of eel Anguilla anguilla (L.) from the Szczecin Firth and adjacent waters. Acta Ichthyol. Piscat. 3: $67-76$

Sures B., Streit B. 2001: Eeel parasite diversity and intermediate host abundance in the River Rhine, Germany. Parasitology 123: $185-191$.

Sures B., Knopf K., Wurtz J., Hirt J. 1999: Richness and diversity of parasite communities in European eels Anguilla anguilla of the River Rhine, Germany, with special reference to helminth parasites. Parasitology 119: 323-330.

Thielen F., Munderle M., Taraschewski H., Sures B. 2007: Do eel parasites reflect the local crustacean community? A case study from the Rhine river system. J. Helminthol. 81: 179-189.

Ubelaker J., KăZić D., Mayberry L., Čanković M. 1981: Parasitism of fishes and other vertebrates of Lake Skadar. In: G.S. Karaman and A.M. Beeton (Eds.), The Biota and Limnology of Lake Skadar. Titograd, pp. 356-383.

Accepted 27 March 2012 